\title{
STRENGTH AND DURABILITY TRAINING IN FOOTBALL PLAYERS
}

\author{
Rade Jovanović
}

\begin{abstract}
Football is one of the world's most widespread sports. In addition to other parameters concerning power, football players need enormous physical fitness. Explosive strength, repetitive strength, and static strength are important parameters for the inclusion of plans and training programs in individual football players.

Numerous studies have shown a significantly greater height and maximum muscle strength while performing vertical jump in elite athletes, compared with examinees in the lower league competition level.
\end{abstract}

Acta Medica Medianae 2017;56(4):66-69.

Key words: explosive strength, muscle, football players, non-athletes, differences

\author{
University \\ Serbia \\ Contact: Rade Jovanović \\ Bul. Nemanjića 74/30, 18000 Niš, Serbia \\ email: radejovanovic75@gmail.com
}

\section{Introduction}

Football is one of the most widespread sports in the world. Footballers need enormous physical preparation, high level of technique in movement, excellent tactical traits and mental maturity. During the course of one match, the players run $8-12 \mathrm{~km}$ (1-3).

Muscle strength is the ability to generate maximum will power. The external force "occurs" between the body of the athlete and the environment. This force is the measure of an athlete's strength. On this basis, the strength of a man is determined as his ability to overcome the external resistance or to resist it by muscular strains (4). In mechanics, power is defined as work done in a unit of time. Vertical jump is a very good indicator of muscle strength and anaerobic abilities.

Explosive power represents the ability to maximize energy mobilization in a unit of time. According to the information so far, the explosive power is of a general type, so a person with a great explosive power of his hands has a large explosive power of the legs, or any muscle group (5). The explosive power of a football player is most pronounced when striking the ball on the goal (by head or foot), jumping, sprinting with or without the ball, and especially when changing the direction of movement into sprint.

Repetitive strength is the ability to perform contractions and decontractions of a certain group of muscles needed to overcome resistance (5).

Static strength is the ability to withstand a certain load without changing the position of the body or body parts (5).

Numerous studies have shown significantly higher values of height and maximum muscle strength when performing a vertical jump in top athletes, compared to lower-level competitor levels (6-8). Superior values of anaerobic parameters and muscle strength parameters are desirable in high-level sports and are likely to somewhat reduce the risk of injury by providing more powerful leaps, shots, dribbles and sprint. It has been clearly demonstrated that the improvement in achievement in individual or series vertical jumps comes after a training program involving explosive training of maximum exertion, electrostimulation, vibration training and plyometrics. Although the performance of vertical vault tests is relatively simple and more specific and more valid than other tests, the results collected from the literature are relatively modest. The lack of test standardization and the unevenness of the results presented (for example, simultaneous comparison of half squat jump with squat jump) make the analysis of the results difficult. Athletes with superior muscular strength and anaerobic alactic ability have the advantage in short activities (lasting up to 15s) which have a primary role in many sports activities. From the biomechanical point of view, movements in a football game, such as ball kicks, duels, spins, spikes, sprints, changes in the direction of movement, head kicks, require a good basis of 
muscle strength and explosiveness. From the physiological aspect, the explosive force itself depends primarily on the permeability of motor synapses, the pulse transmission rate from the center to the periphery of the effector, the number of active motor units and the biochemical state of the muscles (9). Otherwise, football is structurally a very complex game, characterized by various motor activities, of acyclic and cyclic type, that is, movements of different volumes and intensities. Modern developments of the football game, great dynamics, rhythm, require a high level of physical preparation, technique, tactical training, psychological stability, and so on. Continuous increase in load, constant change in pace during matches, require continuous improvement of the players' basic motor skills: strength, speed, endurance, flexibility, coordination, balance, precision. Motoric performance of any football activity, e.g. goal kick, receiving and passing the ball, is a combination of activities that consist of intellectual and motor skills, as well as technical knowledge and as such is a set of thoughtful efforts and motor skills. Reilli, Bangsbo, \& Franks (10) believe that footballers do not have to display a maximum level of motor skills, but they should have an appropriate high level in all abilities, which together represent a combination of activities.

Haugen, Tonnessen, and Seiler (6) investigated the differences in the vertical jump level of the 939 Norway national team football players, with average age $22.1 \pm 4.3$ years, in the period from 1995 to 2010. It was found that midfielders scored lower jumps compared to players in all other positions in the team, an average of $2 \mathrm{~cm}(p$ $<0.05$ ).

Sporis, Jukić, Ostojic, and Milanović (11) found that attackers possess the highest level of explosive muscle abilities compared to all other players in the field. The research involved 270 players (80 defense, midfield and attack players, and 30 goalkeepers). Using the ANOVA method, a statistically significant difference was found in the muscle explosive force displayed in the vertical jump between the attack and defense players, with higher values being obtained from attack players, and even the goalkeepers displayed higher values of explosive power than midfielders.

Gissis et al. (12) determined the vertical jump height for young Greek footballers $(N=54)$ divided into groups: footballers of the young national team of Greece $(N=18)$, quality young players $(N=18)$ and recreational players $(N=18)$. $A$ difference in the height of the jump $(p<0.05)$ was established in favor of the national football selection in relation to the other two groups. The difference between high-quality young footballers and recreational footballers has not been established.

Pivovarnicek, Pupis, Tonhauserova, \& Tokarova, (13) conducted a survey involving 36 footballers from the Slovak national team under the age of 21 and examined the height of the jump during a half squat jump and a jump from a squat with arm swing. The average jump height was 39.0 $\pm 4.2 \mathrm{~cm}$ (Mean \pm Std.Dev.). The highest jump height was determined in attack players (39.9 \pm $4.8 \mathrm{~cm})$, followed by defensive players $(39.6 \pm 5.4$ $\mathrm{cm})$, goalkeepers $(39.2 \pm 4.0 \mathrm{~cm})$ and finally midfielders $(38.0 \pm 3.8 \mathrm{~cm})$.

On the other hand, Mujika, Santisteban, Impellizzeri \& Castagna (14) did not determine a statistically significant difference $(p>0.05)$ concerning the height of the vertical jump (half squat jump with and without arm swing), between professional senior and junior players $(N=17)$.

Tourny-Chollet, Leroy, Léger, and BeuretBlanquart (15), as well as Reilly, Bangsbo, \& Franks (10), stated that there are differences in the muscle strength of football players according to position in the team. The results of this study show significantly lower muscle strength in midfielders than other players.

The difference in the strength of the football players according to the position in the team, i.e. the significantly higher strength of the flexors and extensors of the knee in attackers, compared to goalkeepers $(p<0.001)$ and attackers, compared to defense players $(p<0.001)$ has also been proved by Oberg, Ekstrand, Möller, \& Gillquist (16).

Therefore, among the available researches, the prevailing ones indicate that there are differences in the explosive muscle strength in football players in relation to the position in the team, even in the period of adolescence.

\section{Conclusion}

Strength training, as well as the program of explosive power, should be included in the preparatory and competitive period of the annual training cycle of the football players. It is important to pay attention to health condition of each individual player. 


\section{References}

1. Bangsbo J, Nørregaard L, Thorsøe F. Activity profile of - competition soccer. Can J Sport Sci 1991; 16: 110-6. (PubMed)

2. Smaros G. Energy usage during a football match. In: Vecciet $L$, editor. Proceedings of the 1st International Congress on Sports- Medicine Applied to Football; 1980; Rome. Rome: D. Guaneltivelo, 1980: 795-801.

3. Shephard RJ. Biology and medicine of soccer: an update. Sports Sci 1999; 17: 757-86. (CrossRef) (PubMed)

4. Zatsiorsky VM, Kraemer WJ. Science and practice of strenght trainning. Second edition: Human Kinetics 57A Price Avenue Lower Mitcham, South Australia, 1995.

5. Zec M. Trenažna tehnologija razvoja snage kod fudbalera. Specijalistički rad, Banja Luka, 2008.

6. Haugen TA, Tonnessen E, Seiler S. Anaerobic performance testing of professional soccer players 1995-2010. International journal of Sports Physiology and Performance 2013; 8(2): 148-56. (CrossRef)(PubMed)

7. Ostojić SM, Stojanović M, Ahmetović Z. Vertical jump as a tool in assessment of muscular power and anaerobic performance. Medicinski pregled 2010;63(5-6), 371-5. (CrossRef)

8. Ostojić SM. Elite and non elite soccer players: preseasonal physical and physiological characteristics. Research in Sports Medicine 2004; 12: 143-50. (CrossRef)

9. Bubanj S, Okičić T, Živković M, Stanković R, Bojić I, Bubanj R. Differences in manifested explosive strength tested by means of the vertical jump with and without previous static stretching. Facta Universitatis Series: Physical Education and Sport 2011; 9:2, 151-9.

10. Reilly T, Bangsbo J, Franks A. Anthropometric and physiological predispositions for elite soccer. Journal of Sports Sciences 2000; 18(9): 669-83. (CrossRef) (PubMed)

11. Sporis G, Jukic I, Ostojic SM, Milanovic D. Fitness profiling in soccer: physical and physiological characteristics of elite players. Journal of Strength and Conditioning Research 2009; 23(7), 1947-53. (CrossRef)(PubMed)

12. Gissis I, Papadopoulos C, Kalapothrakos VI, Sotiropoulos A, Komsis G, Manolopoulos E. Strength and speed characteristics of elite, subelite, and recreational young soccer players. Research in Sports Medicine 2006; 14, 205-14. (CrossRef) (PubMed)

13. Pivovarniček $P$, Pupiš $M$, Tonhauserova $Z$, Tokarova M. Relations between morphological variables. SportLogia 2013; 9(2), 186-200.

14. Mujika I, Santisteban J, Impellizzeri FM, Castagna C. Fitness determinants of success in men's and women's football. Journal of Sports Sciences 2009; 27(2), 107-14. (CrossRef)(PubMed)

15. Tourny-Chollet $C$, Leroy $D$, Léger $H$, Beuret-Blanquart F. Isokinetic knee muscle strength of soccer players according to their position. Isokinetics and Exercise Science 2000; 8(4), 187-93.

16. Oberg B, Ekstrand J, Möller M, Gillquist J. Muscle strength and flexibility in different positions of soccer players. International Journal of Sports Medicine1984; 5(4), 213-6. (CrossRef)(PubMed) 


\title{
Revijalni članak
}

UDC: 796.332.015.52

doi: $10.5633 / a m m .2017 .0410$

\section{TRENING SNAGE I IZDRŽLJIVOSTI KOD FUDBALERA}

\author{
Rade Jovanović
}

Univerzitet u Nišu, Fakultet sporta i fizičkog vaspitanja, Niš, Srbija

Kontakt: Rade Jovanović

Bul. Nemanjića 74/30, 18000 Niš, Srbija

email adresa: radejovanovic75@gmail.com

Fudbal je jedan od najrasprostranjenijih svetskih sportova. Od fudbalera se traži ogromna fizička pripremljenost, pored ostalih parametara koji se tiču snage. Eksplozivna snaga, repetitivna snaga, statička snaga su parametri važni za uključivanje plana i programa treninga kod fudbalera individualno.

Brojne studije pokazale su značajno veće vrednosti visine i maksimalne snage mišića prilikom izvođenja vertikalnog skoka kod vrhunskih sportista u odnosu na ispitanike nižerazrednih nivoa takmičenja.

Acta Medica Medianae 2017;56(4):66-69.

Ključne reči: eksplozivna snaga, mišići, fudbaleri, nesportisti, razlike 